\title{
Intracerebral Hemorrhaging Due to Coagulopathy Caused by Latent Advanced Prostate Cancer
}

\author{
Takashi Johno ${ }^{1}$, Hiroyuki Kawano ${ }^{1}$, Tatsuya Hirokawa ${ }^{2}$, \\ Junji Shibahara $^{2}$ and Teruyuki Hirano ${ }^{1}$
}

\begin{abstract}
:
A patient with no medical history was admitted to our hospital with consciousness disturbance and diagnosed with intracerebral hemorrhaging in the bilateral hemisphere based on computed tomography. A blood test showed an abnormal coagulation capacity. He died of intracerebral hemorrhaging 11 hours after the onset. An autopsy revealed latent advanced prostate cancer metastasis to multiple organs. Notably, we found no evidence of intracerebral hemorrhaging, including arteriovenous malformation or cancer metastasis, in the brain. He was ultimately diagnosed with intracerebral hemorrhaging due to coagulopathy associated with latent advanced prostate cancer. Coagulopathy caused by advanced prostate cancer, which was first identified by autopsy, can lead to intracerebral hemorrhaging.
\end{abstract}

Key words: prostate cancer, intracerebral hemorrhaging, disseminated intravascular coagulation

(Intern Med 60: 1763-1767, 2021)

(DOI: 10.2169/internalmedicine.5838-20)

\section{Introduction}

The majority of intracerebral hemorrhaging cases are caused by hypertension. Intracerebral hemorrhaging due to other causes, such as vascular abnormalities, cerebral amyloid angiopathy, and coagulopathy, can also often be encountered.

Coagulopathy, including disseminated intravascular coagulation (DIC), is one cause of intracerebral hemorrhaging or subdural hematoma (1), but it can be difficult to clinically identify the cause of intracerebral hemorrhaging. Prostate cancer relatively commonly causes DIC (2-5). There have been few reports of intracerebral hemorrhaging associated with prostate cancer (6-8), although there have been several reports of acute subdural hematoma in prostate cancer caused by metastases $(9,10)$.

We herein report a rare case of intracerebral hemorrhaging due to coagulopathy caused by prostate cancer that was identified at the autopsy.

\section{Case Report}

A 73-year-old man with no significant history was admitted to our hospital because of the sudden onset of consciousness disturbance. He was in a deep coma, and his extremities showed flaccid paresis; the National Institutes of Health Stroke Scale score was 38. Brain computed tomography (CT) showed intracerebral hemorrhaging in the bilateral cerebral hemispheres, with an estimated hematoma volume of $94 \mathrm{~mL}$, and subdural hematoma (Fig. 1A, B). Truncal CT showed lymph node swelling in the axilla around the clavicle and pleural effusion in both lungs (Fig. 1C). In the bladder, an irregular marginal tumorous and prominent-like structure was detected on CT (Fig. 1D). Magnetic resonance imaging fluid-attenuated inversion-recovery (FLAIR) showed intracerebral hemorrhaging in the right hemisphere and midline shift (Fig. 2A), and MR angiography (MRA) showed no evidence of intracranial vascular malformations (Fig. 2B).

His blood pressure was $149 / 86 \mathrm{mmHg}$, with a regular pulse of 67 beats per minutes. Laboratory values were as follows: a white blood cell count of $4,900 / \mathrm{mm}^{3}$ (normal

${ }^{1}$ Department of Stroke and Cerebrovascular Medicine, Kyorin University, Japan and ${ }^{2}$ Department of Pathology, Kyorin University, Japan Received: July 29, 2020; Accepted: November 11, 2020; Advance Publication by J-STAGE: December 29, 2020

Correspondence to Dr. Hiroyuki Kawano, hkawano@ks.kyorin-u.ac.jp 



Figure 1. A, B: Brain CT shows intracerebral hemorrhaging in the bilateral frontal lobes as well as right hemisphere subdural hematoma. $\mathrm{C}$ : $\mathrm{CT}$ of the trunk shows axillary lymph node swelling and pleural effusion. D: The arrow indicates an abnormal structure in the prostate that was suspected of being limbic irregular masses with varying CT density.
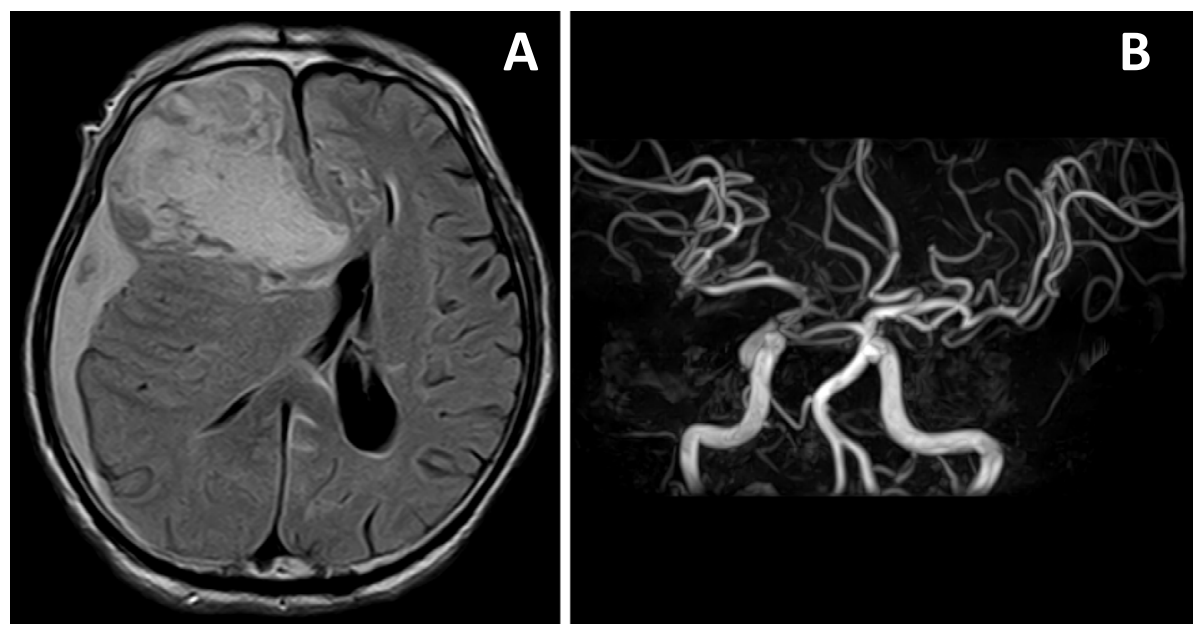

Figure 2. A: MRI (FLAIR) shows intracerebral hemorrhaging in the right hemisphere and midline shift. B: MRA showed no evidence of intracranial vascular malformations.

range $\left.3,300-8,600 / \mathrm{mm}^{3}\right)$, hemoglobin $6.1 \mathrm{~g} / \mathrm{dL}(13.7-16.8 \mathrm{~g} /$ $\mathrm{dL})$, platelet count of $56,000 / \mathrm{mm}^{3}\left(158,000-168,000 / \mathrm{mm}^{3}\right)$, elevated prothrombin time international normalized ratio (PT-INR) of 5.50, activated partial thromboplastin time of 90.6 seconds (27-40 seconds), fibrinogen $<10 \mathrm{mg} / \mathrm{dL}$ (200$400 \mathrm{mg} / \mathrm{dL})$, and D-dimer of $84.3 \mu \mathrm{g} / \mathrm{mL}(0-0.5 \mu \mathrm{g} / \mathrm{mL})$. He had coagulopathy, suggesting DIC based on the criteria of the Japanese Ministry of Health Labor and Welfare, although these findings did not completely meet the International Society of Thrombosis and Haemostasis (ISTH) DIC criteria (11). There were no obvious abnormalities in the blood biochemistry, including renal and liver function tests.
Palliative treatment was performed, and he died 11 hours after the onset.

An autopsy was performed with the consent of the bereaved family. On an external examination, multiple instances of intracerebral hemorrhaging were observed in the subcortex in the bilateral frontal lobes and right midbrain (Fig. 3A, B). The lesion under the right frontal cortex was particularly large and had a perforation to the subarachnoid, leading to brain swelling and a cingulate hernia. A solid lesion was observed in the prostate that extended into the bladder (Fig. 3C). The bone marrow showed multiple solid lesions throughout the whole area. On a microscopic exami- 

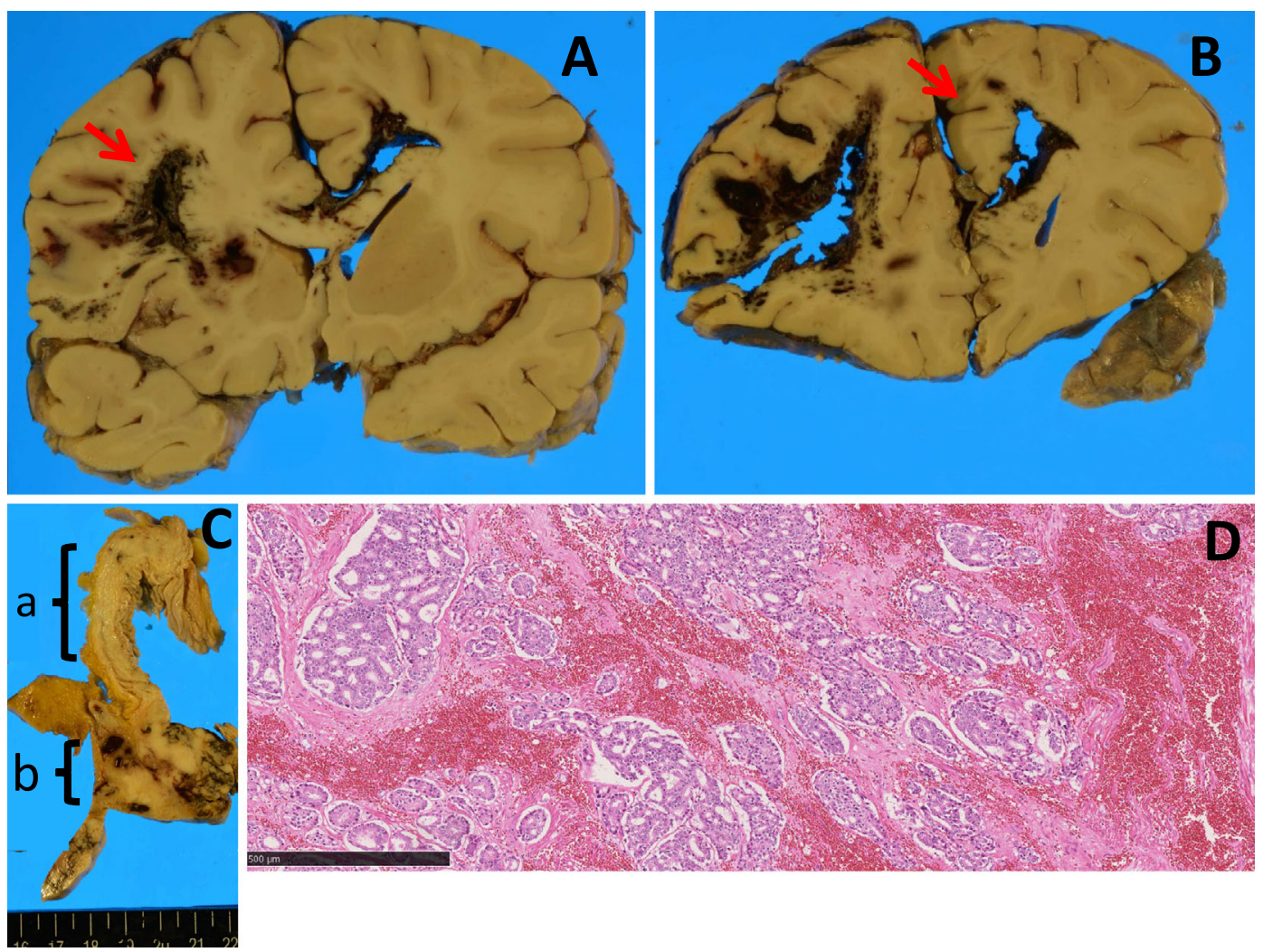

Figure 3. A, B: On an external examination, intracerebral hemorrhaging was noted in the bilateral frontal lobes. C: Macroscopic findings show a protruding fuller lesion in the bladder (a) that is continuous from the prostate with cancer (b). D: Hematoxylin and Eosin staining of prostate cancer shows prostate adenocarcinoma, equivalent to Gleason score $4+4=8$.

nation, prostate adenocarcinoma was observed (Fig. 3D), showing vascular invasion. The prostate carcinoma had spread to multiple lymph nodes (cervical, pulmonary hilar, and paraaortic) and multiple organs (bilateral lungs, thyroid, sternum, and bone marrow). In the bone marrow, the tumor occupied the bone marrow, and the numbers of hematopoietic cells were markedly decreased. Extramedullary hematopoiesis with erythroblast accumulation was observed in the liver and spleen. In the brain, there was no amyloid beta deposition or findings of small-vessel disease, such as lipohyalinosis, microaneurysm, or arteriolosclerosis, that suggested hypertensive changes around the intracranial hematoma, vasculitis, or thrombotic obstruction in the arterioles. The frontal cortex showed no embolization and no tumor cell metastases. Small bleeding findings were observed in many organs and carcinoma lesions other than the intracranial lesions.

\section{Discussion}

We encountered a patient with intracerebral hemorrhaging due to coagulopathy caused by latent advanced prostate cancer.

Metastatic prostate cancer can be a cause of DIC, thrombocytopenia, and acute bleeding (5). In patients with prostate cancer, DIC is relatively common, occurring in $13 \%$ to $30 \%$ of cases (12). There have been only two case reports where intracerebral hemorrhaging was the first manifestation of prostate cancer-related DIC $(13,14)$, six cases where other bleeding was the first manifestation (15-18), and four cases where other symptoms were associated with DIC (18-20)(Table).

Prostate cancer cells express tissue factor (2) that leads to DIC (3). Furthermore, prostate cancer cells produce urokinase-type plasminogen activator (4). Therefore, prostate cancer cells might induce DIC simultaneously through tissue factor and fibrinolysis by urokinase-type plasminogen activator in the advanced stage. Since the autopsy examination in the present patient showed bone marrow metastasis and extramedullary hematopoiesis in the liver and spleen, which led to bone marrow suppression, thrombocytopenia might have been caused by both DIC and bone marrow suppression.

Other bleeding states that can result in intracerebral hemorrhaging in cancer patients are liver metastases, which cause a decrease in clotting factors, and thrombocytopenia resulting from tumor invasion of the bone marrow or the effects of radiation and chemotherapy on the bone marrow (1). However, in the present patient, there were no liver metastases.

In the present patient, prostate cancer was first identified at the autopsy. The number of prostate cancer cases worldwide was about 1.2 million per year in 2018, accounting for $13 \%$ of all cancers in men (21). The number of deaths due 
Table. Characteristics of Patients with Both Latent Prostate Cancer and Disseminated Intravascular Coagulopathy.

\begin{tabular}{|c|c|c|c|c|c|c|c|c|c|c|c|}
\hline Reference & $\begin{array}{c}\text { Age } \\
\text { (years) }\end{array}$ & $\operatorname{sex}$ & $\begin{array}{c}\text { First } \\
\text { manifestation }\end{array}$ & $\begin{array}{l}\text { Hemoglobin } \\
\quad(\mathrm{g} / \mathrm{dL})\end{array}$ & $\begin{array}{l}\text { Platelets } \\
\left(/ \mathrm{mm}^{3}\right)\end{array}$ & PT-INR & $\begin{array}{l}\text { D-dimer } \\
(\mu \mathrm{g} / \mathrm{mL})\end{array}$ & $\begin{array}{l}\text { Fibrinogen } \\
\text { (mg/dL) }\end{array}$ & $\begin{array}{c}\text { FDP } \\
(\mu \mathrm{g} / \mathrm{dL})\end{array}$ & $\begin{array}{c}\text { PSA } \\
(\mathrm{ng} / \mathrm{mL})\end{array}$ & outcome \\
\hline Present case & 73 & Man & $\begin{array}{l}\text { intracerebral } \\
\text { hemorrhaging }\end{array}$ & 6.1 & 56,000 & 5.5 & 84.1 & $<10$ & - & - & $\begin{array}{l}\text { died at } \\
12 \text { hours }\end{array}$ \\
\hline$[13]$ & 80 & Man & $\begin{array}{l}\text { intracerebral } \\
\text { hemorrhaging }\end{array}$ & - & - & 1.5 & 12 & $<50$ & - & 22 & $\begin{array}{c}\text { died before } \\
\text { performing } \\
\text { a biopsy }\end{array}$ \\
\hline$[14]$ & 76 & Man & $\begin{array}{l}\text { intracerebral } \\
\text { hemorrhaging }\end{array}$ & - & 99,000 & 1.76 & $>320$ & $<50$ & - & - & $\begin{array}{l}\text { died at } \\
5 \text { days }\end{array}$ \\
\hline$[15]$ & 66 & Man & $\begin{array}{l}\text { ecchymoses } \\
\text { over the limbs, } \\
\text { laterocervical } \\
\text { hematoma, and } \\
\text { hemothorax }\end{array}$ & 12.1 & 115,000 & & 61.7 & 72 & - & 385 & - \\
\hline [19] & 56 & Man & $\begin{array}{c}\text { dyspnea, } \\
\text { general fatigue, } \\
\text { lumbago }\end{array}$ & 7.6 & 13,000 & 1.1 & - & 478 & 28.6 & 4,125 & $\begin{array}{c}\text { died at } \\
34 \text { weeks }\end{array}$ \\
\hline [16] & 56 & Man & $\begin{array}{c}\text { epistaxis, } \\
\text { massive upper } \\
\text { gastrointestinal } \\
\text { bleeding }\end{array}$ & - & - & - & - & - & - & - & - \\
\hline$[17]$ & 70 & Man & $\begin{array}{l}\text { rectorrhagia, } \\
\text { lumbar pain }\end{array}$ & - & 25,000 & - & 2.47 & 127 & - & 8,138 & died \\
\hline \multirow[t]{5}{*}[18]{} & 80 & Man & hematuria & - & 84,000 & 1.43 & - & 73 & 36.4 & 1,678 & $\begin{array}{l}\text { died at } \\
509 \text { days }\end{array}$ \\
\hline & 52 & Man & intercostal pain & - & 41,000 & 1.33 & - & 98 & 380 & 4,482 & $\begin{array}{c}\text { died at } \\
1,336 \text { days }\end{array}$ \\
\hline & 74 & Man & back pain & - & 38,000 & 1.13 & - & 197 & 266.8 & 818 & $\begin{array}{l}\text { died at } \\
192 \text { days }\end{array}$ \\
\hline & 74 & Man & $\begin{array}{l}\text { gingivitis } \\
\text { bleeding }\end{array}$ & - & 60,000 & 1.22 & - & 130 & 60 & 741 & $\begin{array}{l}\text { died at } \\
594 \text { days }\end{array}$ \\
\hline & 60 & Man & $\begin{array}{l}\text { palpitation, } \\
\text { dizziness, } \\
\text { ecchymoses }\end{array}$ & - & 86,000 & 1.13 & - & 115 & 262 & 1,250 & $\begin{array}{l}\text { died at } \\
794 \text { days }\end{array}$ \\
\hline [20] & 76 & Man & $\begin{array}{l}\text { confusion and } \\
\text { drowsiness }\end{array}$ & 9 & 90,000 & - & - & - & - & - & $\begin{array}{l}\text { died at } \\
4 \text { days }\end{array}$ \\
\hline
\end{tabular}

to prostate cancer was about 310,000 per year, accounting for $6.6 \%$ of all cancer patients $(21,22)$. When prostate cancer is first identified at an autopsy, as in the present case, it is called latent cancer. A systematic review of 29 autopsybased studies published from 1948-2013 reported that the estimated prevalence of latent prostate cancer was $59 \%$ in men $>79$ years old (23). Therefore, latent prostate cancer in older men is not rare. Prostate cancer should be considered a potential cause of coagulopathy in patients with intracerebral hemorrhaging with no known cause.

In conclusion, latent advanced cancer resulted in coagulopathy and caused intracerebral hemorrhaging.

The authors state that they have no Conflict of Interest (COI).

\section{References}

1. Rogers LR. Cerebrovascular complications in patients with cancer. Semin Neurol 30: 311-319, 2010.

2. Abdulkadir SA, Carvalhal GF, Kaleen Z, et al. Tissue factor expression and angiogenesis in human prostate carcinoma. Hum Pathol 31: 443-447, 2000.
3. Levi M. Disseminated intravascular coagulation. Crit Care Med 35: 2191-2195, 2007.

4. Cozzi PJ, Wang J, Delprado W, et al. Evaluation of urokinase plasminogen activator and its receptor in different grades of human prostate cancer. Hum Pathol 37: 1442-1451, 2006.

5. Duran I, Tannock IF. Disseminated intravascular coagulation as the presenting sign of metastatic prostate cancer. J Gen Intern Med 21: C6-C8, 2006.

6. Claes F, Verhagen CV, Verhagen WI, Schaafsma E, Rongen RJ. Acute isodense intracerebral haematoma due to coagulopathy associated with prostate cancer. Clin Neurol Neurosurg 109: 520-522, 2007.

7. Kojima A, Okui S. Intracranial hemorrhage as the initial presentation of disseminated intravascular coagulation in association with malignancy. J Stroke Cerebrovasc Dis 21: 912, 2012.

8. Braun JS, Novak R, Torzewski M, Soehngen D. Intracerebral hemorrhages, fibrinolysis, and prostate carcinoma. J Neurol 249: 478479, 2012.

9. Knieling A, Diac MM, Rişcanu LA, Ză voi RE, Bulgaru Iliescu D. Subdural hematoma - a cause of death in the development of a prostatic adenocarcinoma with dural metastases: case report. Rom J Morphol Embryol 58: 1549-1553, 2017.

10. Ambiavagar PC, Sher J. Subdural hematoma secondary to metastatic neoplasm: a case report of two cases and a review of the literature. Cancer 42: 2015-2018, 1978.

11. Taylor FB, Toh CH, Hoots WK, Wada H, Levi M; Scientific Sub- 
committee on Disseminated Intravascular Coagulation (DIC) of the International Society on Thrombosis and Haemostasis (ISTH). Towards definition, clinical and laboratory criteria, and a scoring system for disseminated intravascular coagulation. Thromb Haemost 86: 1327-1330, 2001.

12. Smith JA Jr, Soloway MS, Young MJ. Complications of advanced prostate cancer. Urology 54: 8-14, 2004.

13. Braun JS, Novak R, Torzewski M, Soehngen D. Intracerebral hemorrhages, fibrinolysis, and prostate carcinoma. J Neurol 249: 478479, 2002.

14. Kojima A, Okui S. Intracranial hemorrhage as the initial presentation of disseminated intravascular coagulation in association with malignancy. J Stroke Cerebrovasc Dis 21: 912.e1-e3, 2012.

15. Palma Anselmo M, Nobre de Jesus G, Lopes JM, Victorino RM, Meneses Santos J. Massive bleeding as the first clinical manifestation of metastatic prostate cancer due to disseminated intravascular coagulation with enhanced fibrinolysis. Case Rep Hematol 2016: 7217915 .

16. Salako AA, Arowolo OA, Omonisi EA, Adisa AO, Titiloye NA, Adelusola K. Incidental carcinoma of the prostate gland presenting with initial manifestation of disseminated intravascular coagulopathy (dic) in a middle aged man: a case report. Cases J 2: 144, 2009.

17. Navarro M, Ruiz I, Martin G, Cruz JJ. Patient with disseminated intravascular coagulation as the first manifestation of adenocarcinoma of the prostate. Risks of prostatic biopsy. Prostate Cancer
Prostatic Dis 9: 190-191, 2006.

18. Ohtake N, Kurita S, Fukabori Y, et al. Clinical study on prostate cancer initially presenting with disseminated intravascular coagulation syndrome. Hinyokika Kiyo 44: 387-390, 1998 (in Japanese, Abstract in English).

19. Minato N, Takada T, Koga M, Sugao H. Prostate cancer with disseminated carcinomatosis of bone marrow initially presenting with disseminated intravascular coagulation syndrome: a case report. Hinyokika Kiyo 58: 249-253, 2012 (in Japanese, Abstract in English).

20. Grignon D, Turnbull DI, Lohmann RC. Carcinoma of the prostate presenting as acute disseminated intravascular coagulation. CMAJ 135: 775-776, 1986.

21. World Health Organization. Global Cancer Observatory [Internet]. [cited 2020 May 6]. Available from: https://gco.iarc.fr/today/home.

22. Torre LA, Bray F, Siegel RL, Ferlay J, Lortet-Tieulent J, Jemal A. Global cancer statistics, 2012. CA Cancer J Clin 65: 87-108, 2015.

23. Bell KJ, DelMar C, Wright G, Dickinson J, Glasziou P. Prevalence of incidental prostate cancer A systematic review of autopsy studies. Int J Cancer 137: 1749-1757, 2015.

The Internal Medicine is an Open Access journal distributed under the Creative Commons Attribution-NonCommercial-NoDerivatives 4.0 International License. To view the details of this license, please visit (https://creativecommons.org/licenses/ by-nc-nd/4.0/).

(C) 2021 The Japanese Society of Internal Medicine

Intern Med 60: 1763-1767, 2021 